\title{
"Would you like rice with that?" Wild rantings of a part-time plum blossom
}

\author{
Mari Sasano \\ "Désirez-vous du riz avec cela?" \\ Contemplations d'une serveuse à temps-partiel
}

"Contemplations" est à la fois un monologue et un manifeste écrit du point de vue d'une serveuse qui travaille dans un restaurant japonais appartenant à un ami de sa famille, et qui déteste son travail. Les raisons pour lesquelles elle déteste son travail sont mentionées ironiquement tout au long du texte. Est-ce parce qu'elle est une jeune Japonaise-Canadienne travaillant dans un restaurant japonais-canadien et que les clients présupposent qu'elle est la fille $d u$ propriétaire et la traitent avec condescendance? Est-ce parce que la popularité du sushi dans les années ' 80 a trop vulgarisé la cuisine japonaise? Est-ce parce que les pourboires sont misérables? Sa patience est poussée à l'extrême par une cliente particulièrement déplaisante. Elle lui dit de ne jamais revenir"personne ne doit traiter ses servantes comme ça!"

I am a waitress and I hate my job.

Specifically, I work for my parents' friends' Japanese restaurant, a Mom ' $n$ ' Pop joint built out of a converted pizza place (it was years ago, though the red vinyl booths and tiffany chandeliers are still there). Mr. N (described in a restaurant review as a "Japanese Tom Skerritt") and Ray at the sushi bar and genuine Japanese-Canadian housewives in the kitchen making good homecookin' the likes of tempura and udon, even tempura udon. Both of the $\mathrm{N}^{\prime}$ s sons are dishwashers and general kitchen slaves. Me and two or three other twentysomething women work the front. I got the job one evening while dining with my family. "Sure, I'd love to help out at the restaurant!"

Ineeded the dough. What with grad school and all. 
What is it about Japanese restaurants that attracts so many assholes? These guys (a few women, too) are living their eighties' sushi bar fantasies, totally out of Rising Sun. I'm expected to be this quiet Oriental serveuse devoid of opinion and skill. And I also get people who bow at me a lot. Get real. The sushi chefs are the stars here.

\section{"Gimme another sake, Victor."}

They always call him by his English name. They order by the piece (why order tuna by the piece?) and ask for really hot sake. They talk about golf. One woman comes in here alone, chats up whoever's making her sushi, orders the sushi that we had to name after her. She invented it. Avocado. Tempura shrimp. Cucumber. Tobiko. Mayonnaise. Disgusting. Lays down a wad of cash and goes home.

These people have money, but they're losers.

There's a guy who comes in smoking an obnoxious cigar. He raves about the gyoza, which is hardly haute cuisine. "What's that crazy chinaman doing behind there?" he says and I want to punch his lights out. Instead, I flirt with him, but in the kitchen I make sure to stick my fingers in his doggie bag. He tips exactly $10 \%$.

And then there is the cast of 90210. "Could I have a Diet Coke? Are you sure that's Diet?" Two big, but short, men (one literally in a muscle shirt) and two model-type women, midriffs showing. They couldn't be over 19. Smoke a lot-reduces the appetite. They call the rest of their friends on their cell phones.

Just because I'm quiet and nice doesn't mean that you're NOT a fucking idiot.

I get a nasty look from sake-guy when I smirk and laugh at him when he says, all masculine-like, "Beef Tataki- only the men like it." Excuse me, mister, but the lady here likes her raw meat just fine. A mediocre international-class figure skater has a fit (as only 17 year olds can do) when she thinks she finds mayonnaise in her futomaki. "What," says her father, "is this? It'll throw off her training!" A table of three comes in. The child puts more soy sauce on his rice than he should, then dumps it on the floor. I clean it up, get the kid more rice and some crayons to keep him 
floor. I clean it up, get the kid more rice and some crayons to keep him out of trouble. They leave me a 3\% tip. A woman asks for things that don't appear on the menu, substitutes tobiko (\$2.50) for salmon (\$1.50) in her sushi combo then leaves no tip. I ask her what's wrong and she tells me, "I'd rather not discuss it."

Would they act this way in a French restaurant? Do they think I'm the sushi chef's daughter (yes they do!) and that I don't need the money? "We're the only Japanese restaurant in the city that hires Japanese girls," the dishwasher says to me. Evidently, some people think that Japanese girls only need the money for nice clothes. They are brought up in good families and get married. They are nice and quiet and smart and make good hostesses.

\section{....and take that!}

I go to work because they feed me well. I manage to get double minimum wage if I include tips. So I can pay my rent. So I can finish my degree. So I can work at other restaurants, "It's good experience."

When customers ask for the impossible or treat me like I'm some subhuman thing, I want to say, "Enough! Don't come back! Good night!" Which of course, I never do. Well, maybe once or twice.

We have some good regular customers who respect what the kitchen can do for them. Other customers, rather than actually complaining (which can carry you a long way if you're nice about it), they lash out at me. What do they think they're going to accomplish? Hey, nobody has to treat their servants like that!

PS: All these things are true! 